\title{
Development of macrofaunal community structure in mussel beds on the northern East Pacific Rise
}

\author{
J. C. Dreyer ${ }^{1,2}$, K. E. Knick ${ }^{1,2}$, W. B. Flickinger ${ }^{1}$, C. L. Van Dover ${ }^{1, *}$ \\ ${ }^{1}$ Biology Department, The College of William \& Mary, Williamsburg, Virginia 23187, USA \\ ${ }^{2}$ Present address: Virginia Institute of Marine Science, PO Box 1346, Gloucester Point, Virginia 23062, USA
}

\begin{abstract}
Comparisons of macrofaunal community structure (species composition, abundance, biovolume, rank order, species richness, diversity) in hydrothermal vent mussel beds at $9^{\circ} 50^{\prime} \mathrm{N}(9 \mathrm{~N})$ on the East Pacific Rise were made from analysis of multiple quantitative samples collected in 1999 and 2001 from each of 3 mussel beds of known age (4 to $8 \mathrm{yr}$ in 1999). In addition to this time series approach, a chronosequence based on 2001 samples from 4 mussel beds at $9 \mathrm{~N}$ and 1 mussel bed at $11^{\circ} 25^{\prime} \mathrm{N}(11 \mathrm{~N})$ allowed comparison of macrofaunal community structure for mussel beds ranging in age from 6 to $>14 \mathrm{yr}$. Many aspects of community structure (rank abundance patterns, dominant species, and diversity) were similar in 1999 and 2001 samples. Young (6 to $7 \mathrm{yr}$ ) and old (10 to $14 \mathrm{yr}$ ) mussel beds sampled in 2001 could be distinguished using multivariate analyses, based on species abundance and species biovolume matrices, but the differences were in the relative abundance of the dominant species rather than in any substantial changes in the identity of the dominant species. The limpet Lepetodrilus elevatus was the dominant species at all sites in terms of abundance and biovolume; it and other dominant species may have slightly greater fitness compared to other species that allows them to persist as dominants regardless of the age or location of mussel beds. Decreasing biovolume of macrofaunal communities sampled at $9 \mathrm{~N}$ and $11 \mathrm{~N}$ in 2001 was correlated with increasing age of the mussel beds and is postulated to be largely a response to biological processes; including competition for inorganic substrates by free living and symbiotic chemoautotrophs and mussel induced mortality of larvae of macrofaunal species, rather than the result of waning hydrothermal activity.
\end{abstract}

KEY WORDS: Hydrothermal vent - Chemosynthetic community · Succession · Chronosequence · Diversity $\cdot$ Abundance $\cdot$ Biomass

\section{INTRODUCTION}

Soon after their discovery in 1977, hydrothermal vents were characterized as dynamic and ephemeral environments (e.g. Grassle 1986, Fustec et al. 1987, Hessler et al. 1988, Haymon et al. 1991, Johnson et al. 1994), and the importance of transitory venting on community attributes-including the longevity of a community, its composition and structure, and aspects of succession-was appreciated early in the study of vent ecosystems (e.g. Klitgord \& Mudie 1974, Crane \& Ballard 1980, Haymon \& Macdonald 1985, Fustec et al. 1987, Hessler et al. 1988). There are some vent sites (notably all of those so far known on the Mid-Atlantic
Ridge) where there have been no substantial changes in the megafaunal communities since the sites were first discovered 2 decades ago, even including a site punctured and perturbed by multiple drill holes (Humphris et al. 1995) that opened new, local sites of venting (Copley et al. 1999). The prevailing view, however, is that vent communities are unstable, varying dramatically in composition and structure over time, with especially rapid transitions during the commencement and cessation of fluid flow (e.g. Tunnicliffe et al. 1997, Shank et al. 1998, Mullineaux et al. 2000, 2003, Tsurumi \& Tunnicliffe 2001). The least stable vent communities reported to date may be those associated with large sulfide edifices in vent fields on the Juan de Fuca 
Ridge. Megafaunal and macrofaunal invertebrate species occupying these sulfide edifices make up patchy assemblages that shift predictably over days or months as fluid flux shifts on decimeter scales and as biological interactions progress. The result is the vent analogue of the 'chronic disturbance model' of Horn (1976), wherein species colonize areas left open by the death of another species, provided adults and propagules are present (Sarrazin et al. 1997, Sarrazin \& Juniper 1999).

Transitions in the composition of the dominant megafaunal invertebrate species observed at vents on the East Pacific Rise (EPR) and Galapagos Spreading Center represent a second style of community dynamics that reflects the decadal (or less) scale of hydrothermal cycles on these ridge axes (Fustec et al. 1987, Hessler et al. 1988, Shank et al. 1988). At these vents, biological succession through the hydrothermal cycle begins with initial colonization by microorganisms and motile invertebrates (e.g. bythograeid crabs), followed by recruitment of tubeworms (Tevnia jerichonana, then Riftia pachyptila), then mussels (Bathymodiolus thermophilus), and, then, in some instances, clams (Calyptogena magnifica) (Haymon et al. 1993, Shank et al. 1998, Mullineaux et al. 2000). It is impossible to cite an average duration for each of these successional phases, but mussel beds can persist for 10 to $20 \mathrm{yr}$ (C. L. Van Dover pers. obs.).

Where benthic biogenic structures such as mussel beds or tubeworm clumps are persistent at hydrothermal vents on the EPR, they are colonized by a diverse assemblage of macrofaunal invertebrates (e.g. Van Dover 2002a, 2003). The structure of this macrofaunal community is expected to respond to changes in fluid flux as well as to positive and negative interactions among species, indirect effects of consumers, availability of recruits, etc. (reviewed in Menge \& Branch 2001), such that the communities vary over space and time. Experimental approaches, for example, suggest that environmental conditions and biological interactions modify patterns of settlement and colonization at hydrothermal vents (e.g. Micheli et al. 2002, Mullineaux et al. 2003).

Inferred spatial and temporal variability in factors that control community structure leads to the prediction that community structure of macrofauna associated with mussel beds will be heterogeneous in time and space. We test this hypothesis by sampling 3 mussel beds at the 9N vent field on the EPR in 1999 and again $\sim 2$ yr later, and comparing a variety of community structure attributes (species composition, abundance, biovolume) between years and among sites. We also sample mussel beds of different ages (a chronosequence) to describe the development of macrofaunal community structure over the life of a persistent mussel bed.

\section{MATERIALS AND METHODS}

Study site characteristics (overview). The $9 \mathrm{~N}$ $\left(9^{\circ} 50^{\prime} \mathrm{N}, 104^{\circ} 17^{\prime} \mathrm{W}\right.$; 2490 to $\left.2500 \mathrm{~m}\right)$ and $11 \mathrm{~N}\left(11^{\circ} 25^{\prime} \mathrm{N}\right.$, $103^{\circ} 47^{\prime} \mathrm{W} ; 2480 \mathrm{~m}$ ) vent fields on the northern EPR (Fig. 1) include discrete mussel bed (Bathymodiolus thermophilus) communities of different ages. B. thermophilus is host to sulfur-oxidizing, chemoautotrophic endosymbiotic bacteria in its gills (Fiala-Médioni 1984, Le Pennec \& Hily 1984). The vent mussel is capable of

A
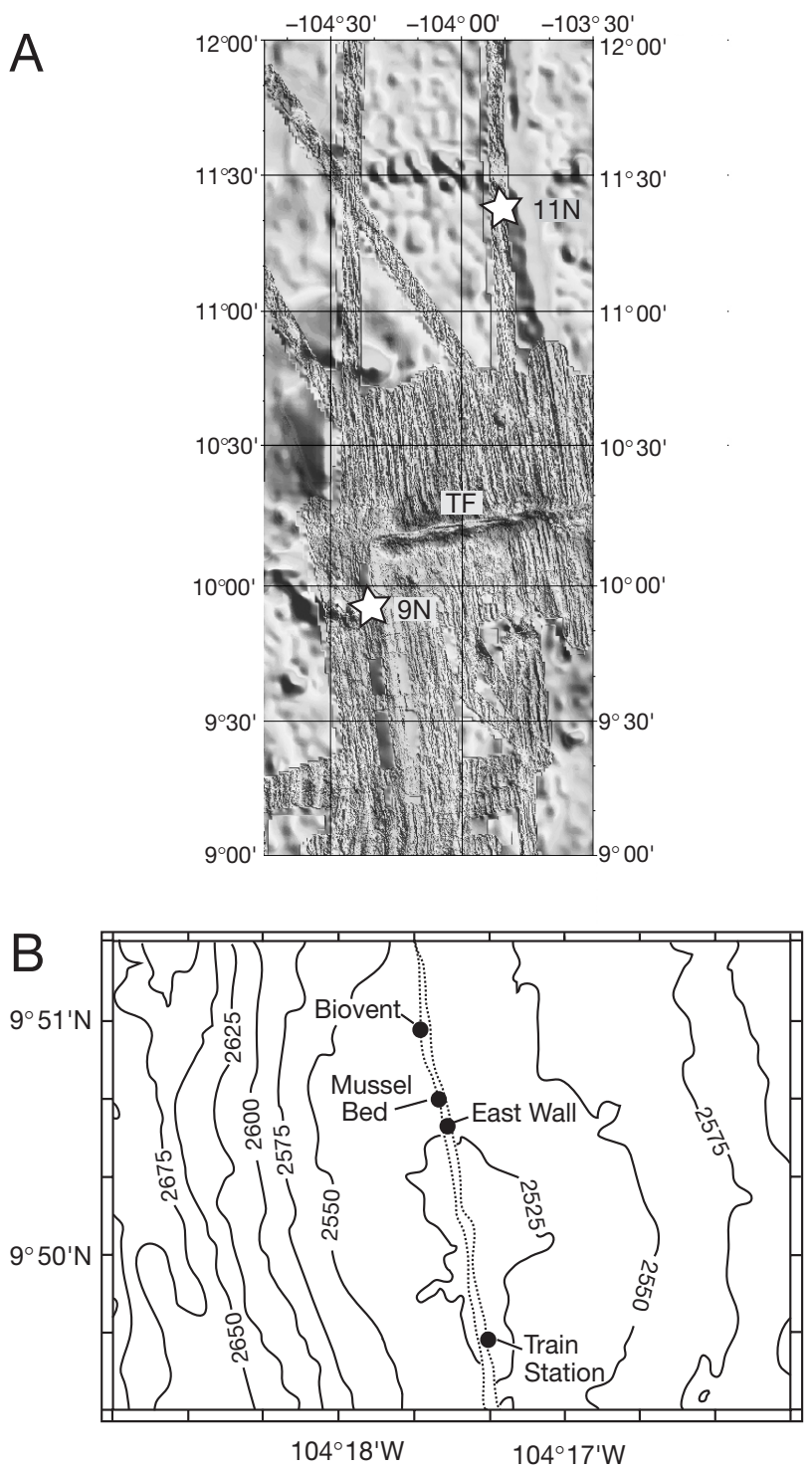

Fig. 1. (A) $9 \mathrm{~N}\left(9^{\circ} 50^{\prime} \mathrm{N}\right)$ and $11 \mathrm{~N}\left(11^{\circ} 25^{\prime} \mathrm{N}\right)$ vent fields on the northern East Pacific Rise (EPR). Base map from the RIDGE Multibeam Synthesis Project (http://ocean-ridge.ldeo.columbia.edu). TF: Clipperton Transform Fault between the 2 ridge segments that host the vent fields. (B) Detail of $9 \mathrm{~N}$ vent field on the EPR showing locations of East Wall (EW), Train Station

(TS), Biovent (BV), and Mussel Bed (MB) mussel beds 
filter feeding (Page et al. 1991), but derives most of its nutrition from its symbionts (reviewed in Fisher 1990, Childress \& Fisher 1992).

General descriptions of the $9 \mathrm{~N}$ vent field are provided by Shank et al. (1998) and Van Dover (2003), among others. The $9 \mathrm{~N}$ mussel beds are located along an $\sim 2.5 \mathrm{~km}$ extent of the ridge axis (Fig. 1), are irregular in shape, and range from 20 to $50 \mathrm{~m}$ in maximum dimension. Point temperature measurements at $9 \mathrm{~N}$ mussel beds ranged between 2 and $11^{\circ} \mathrm{C}$ during an 8 mo interval; average temperatures in pairs of probes (separated horizontally by $1 \mathrm{~m}$ and embedded among mussels) ranged from 2.5 to $9^{\circ} \mathrm{C}$ (C. L. Van Dover unpubl. data).

The $11 \mathrm{~N}$ vent field was first visited by the DSV 'Alvin' in 1988 (Thompson et al. 1989) and consisted of an active black smoker chimney and beds of bivalves (clams, mussels; C. L. Van Dover pers. obs.). In 2001, large mussels (Bathymodiolus thermophilus) and clams (Calyptogena magnifica) formed narrow $(\sim 1 \mathrm{~m})$ irregular low mounds that traced the location of cracks in the basalt. Shimmering water and swarming amphipods were evident above some of the mounds of bivalves.

Three mussel beds at 9N (East Wall [EW], Train Station [TS], Biovent [BV] were quantitatively sampled in November 1999 as part of a biogeographic comparison of mussel bed community structure at vents on the northern and southern EPR (Van Dover 2003) and were re-sampled in December 2001. For chronosequence comparisons, 2 additional mussel beds were sampled in 2001 (Mussel Bed [MB] at 9N and the $11 \mathrm{~N}$ mussel bed). In 2001, mussel bed ages were estimated to be: EW $\sim 6 \mathrm{yr}<\mathrm{TS} \sim 7 \mathrm{yr}<\mathrm{BV} \sim 10 \mathrm{yr} \leq \mathrm{MB} \sim 10 \mathrm{yr}<11 \mathrm{~N}$ $\sim 14$ yr. Age estimates are derived from records of submersible observations. Only the EW and TS mussel beds post-date the 1991 volcanic eruption at 9N (Haymon et al. 1993). These mussel beds represent the complete set of mussel bed ages that were logistically feasible to study at the $9 \mathrm{~N}$ and $11 \mathrm{~N}$ sites.

Sample collection and processing. A replicated sampling design was used for time series ( 3 sites $\times 5$ to 6 quantitative samples per site) and chronosequence ( 5 sites $\times 5$ or 6 [12 at $11 \mathrm{~N}$ ] quantitative samples per site) comparisons. The 2001 time series and chronosequence samples for EW, TS, and BV were not independent collections; i.e. the same samples were used for the 2 types of analyses.

Quantitative samples were collected haphazardly from each mussel bed using 'pot' samplers that retain organisms associated with the mussels (see Van Dover 2002a). The pots, each lined with a kevlar bag, were manipulated into the mussel beds until they reached the basalt underneath; a drawstring was used to close the bag around the mussels. Qualitative samples (1 to
3 per site) were collected using a kevlar lined scoop and were stored in individual bio-boxes with closeable lids. Data from qualitative and quantitative samples were used for species-effort curves; all other analyses used only quantitative samples.

Each pot sampled a maximum volume of 11 l over an area of $531 \mathrm{~cm}^{2}$. Mussel volume sampled $\left( \pm 0.1 \mathrm{l}_{\text {; }}\right.$ determined by displacement) was chosen for standardization of macrofaunal abundance and biovolume data (quantitative samples only) instead of the sampling device volume or foot print (area), due to the 3-dimensional structure of the mussel beds $(50+\mathrm{cm}$ vertical relief) and the consequent unequal sampling effort in each mussel pot.

On deck, mussels were rinsed 3 times in cold, filtered $(10 \mu \mathrm{m})$ seawater. To compare the mussel population structure among beds (Kolmogorov-Smirnov Test (KS); S-PLUS, V6.2), size-frequency histograms were generated from length measurements $( \pm 0.1 \mathrm{~mm})$ of all mussels (>5 mm) sampled quantitatively. Dry tissue weights of mussels $( \pm 0.01 \mathrm{~g})$ were obtained from a systematic sub-sample that represented range of sizes sampled. Mussel dry weight versus shell length was used as a mussel condition index and comparisons of mussel condition between 1999 and 2001 were made using an analysis of co-variance (ANCOVA, MiniTab V13.20) of log-transformed shell length and tissue dry weight.

Mussel washings and associated invertebrates were collected onto coarse $(250 \mu \mathrm{m})$ sieves, preserved in $10 \%$ buffered formalin $(24 \mathrm{~h})$, and stored in $70 \%$ ethanol. These samples were sorted twice under a dissecting microscope, the second sort after the addition of Rose Bengal, a biological stain that enhances the visibility of small organisms. Individuals were identified to the lowest taxonomic level possible (i.e. morphological species) with reference to published descriptions, voucher specimens in the archival collections of C. L. Van Dover, and consultation with taxonomic experts. Those taxa considered to be meiofauna (copepods, ostracods, mites, nematodes) were excluded from this study. Large specimens (i.e. zoarcid fish Thermarces cerberus, galatheid squat lobsters Munidopsis subsquamosa, bythograeid crabs Bythograea thermydron) observed in situ but not sampled, were not included in the data analysis, although juveniles of these species in samples were included. As in previous studies, we did not consider Branchipolynoe symmytilida, the commensal polychaete that lives in the mantle cavities of the mussels, to be a part of the macrofaunal community living among the mussels. Mussels < 5 mm (arbitrary cut off; Van Dover 2002a) were included because this life history stage is part of the associated fauna rather than a structural component of the mussel bed. 
Non-mussel biovolumes $( \pm 0.1 \mathrm{ml})$ were determined by ethanol displacement in graduated cylinders. Biovolume of gastropod species represent the biovolume of the soft tissues only; these biovolumes were determined using a correction factor derived from representative subsets of specimens for each species, whose volume was measured before and after their shells were removed by dissolution in dilute $\mathrm{HCl}$. Biovolumes were standardized per liter of mussel volume collected from quantitative samples only. Macrofaunal species contributing $<1 \%$ of the total biovolume were excluded from the statistical analyses. Species abundance and species biovolume matrices are available on request from the corresponding author.

Rank abundance and diversity measures. Rank abundance plots were generated from the samplebased percent contribution of individuals within species to total abundance or total biovolume. Data from quantitative and qualitative samples were used to calculate species richness and species density using cumulative species effort curves for each vent site. EstimateS (Colwell 1997; randomization operations = 100, without replacement) was used to randomize the sample data and eliminate the effect of sample order. Effort was expressed as the cumulative number of individuals sampled (for species richness) and as cumulative mussel volume sampled (for species density). Where comparisons of species richness or density among samples were made, effort was standardized to the level of the smallest number of individuals (n) or sample volume (V) in any one collection (i.e. $S_{\mathrm{n}}$ or $S_{\mathrm{V}}$ ). The Shannon diversity index $\left(H^{\prime}{ }_{\log }\right.$ e), Pielou's evenness index $\left(J^{\prime}\right)$, and Fisher's $\alpha$ were calculated for standardized $\left(\mathrm{l}^{-1}\right.$ mussel volume sampled) data using Primer v5 (Clark \& Gorley 2001). $H^{\prime}$ is a measure of uncertainty where the maximum uncertainty occurs when each of the species is equally represented (Hayek \& Buzas 1997). $J^{\prime}$ provides a measure of evenness, i.e. the extent to which individuals are equally partitioned between species (Hayek \& Buzas 1997). Fisher's $\alpha$ is interpreted as the expected number of species to be represented by one individual (Hayek \& Buzas 1997).

Chronosequence analyses. Regression analysis was used to test for relationships between standardized, log transformed mean abundance or mean biovolume of macrofauna and mussel bed age for mussel beds sampled at $9 \mathrm{~N}$ in 2001 only (MiniTab,V13.20). Analysis of variance (ANOVA) was used to compare mean abundance and biovolume in chronosequence samples of differing ages. Where a significant difference was detected for an ANOVA ( $p<0.05$ ), Tukey's multiple comparison test was used to test for specific differences.

Multidimensional scaling (MDS) and cluster analysis techniques were used to compare community structure among mussel beds. Similarity matrices for quantitative data were generated using Bray-Curtis coefficients using square-root-transformed, standardized abundance data (PRIMER V5; Clarke \& Gorley 2001). The Bray Curtis computation is not affected by joint absences, i.e. this coefficient of similarity depends only on species that are present in one or the other (or both) samples and not on species that are absent from both samples. The square-root transformation ensures both the very abundant and mid-range species contribute to the similarity matrix (Clarke \& Gorley 2001). Analysis of similarity (ANOSIM; PRIMER V5) was calculated from standardized, quantitative samples to determine significant differences (indicated by the Global R value) between groupings of mussel beds identified in MDS plots. We used Clark \& Gorley's (2001) interpretation of the $\mathrm{R}$ statistic for pairwise groups: $\mathrm{R}>0.75$, groups well separated; $\mathrm{R}>0.5$ groups overlapping but clearly different; $\mathrm{R}<0.25$ groups barely separable. Contributions of species to the dissimilarity between paired sites from each year, between young and old age groups of mussel beds, and between $9 \mathrm{~N}$ and $11 \mathrm{~N}$ mussel beds were calculated using the SIMPER subroutine of PRIMER V5.

\section{RESULTS}

\section{Mussel size frequency distributions and condition indices}

Mussel size frequency distributions in EW, TS, and BV samples were patently different in 1999 and 2001 due to the abundance of mussel recruits $(<5 \mathrm{~mm})$ in 1999 (up to $76 \%$ of the total number of mussels collected in quantitative samples) and their near absence $(<2 \%)$ in 2001 (Fig. 2). When mussel recruits $(<5 \mathrm{~mm}$ shell length) were excluded from statistical analyses, there was no change in the size frequency distribution of mussels at EW between 1999 and 2001 (median mussel length, 1999: $75 \mathrm{~mm}, 2001$ : $78 \mathrm{~mm}, \mathrm{~K}-\mathrm{S}, \mathrm{p}=$ $0.07)$; median length of mussels in the quantitative samples increased between 1999 and 2001 at TS (median mussel length, 1999: $84 \mathrm{~mm}, 2001: 92 \mathrm{~mm}$, K-S, p = 0.03) and BV (median mussel length, 1999: 88 $\mathrm{mm}, 2001: 130 \mathrm{~mm}, \mathrm{~K}-\mathrm{S}, \mathrm{p}<0.001$ ).

Mussel size frequency distributions (exclusive of recruits) in samples from the chronosequence mussel beds (2001) were significantly different from one another $(p<0.001)$, with a progression of median shell lengths of EW $78 \mathrm{~mm}<$ TS $92 \mathrm{~mm}<$ MB $103 \mathrm{~mm}<$ BV $130 \mathrm{~mm}<11 \mathrm{~N} 151 \mathrm{~mm}$. This hierarchy of median shell length matches the hierarchy of estimated ages of the mussel beds. The $11 \mathrm{~N}$ mussel size-frequency distribution was markedly skewed toward large mussels: none 


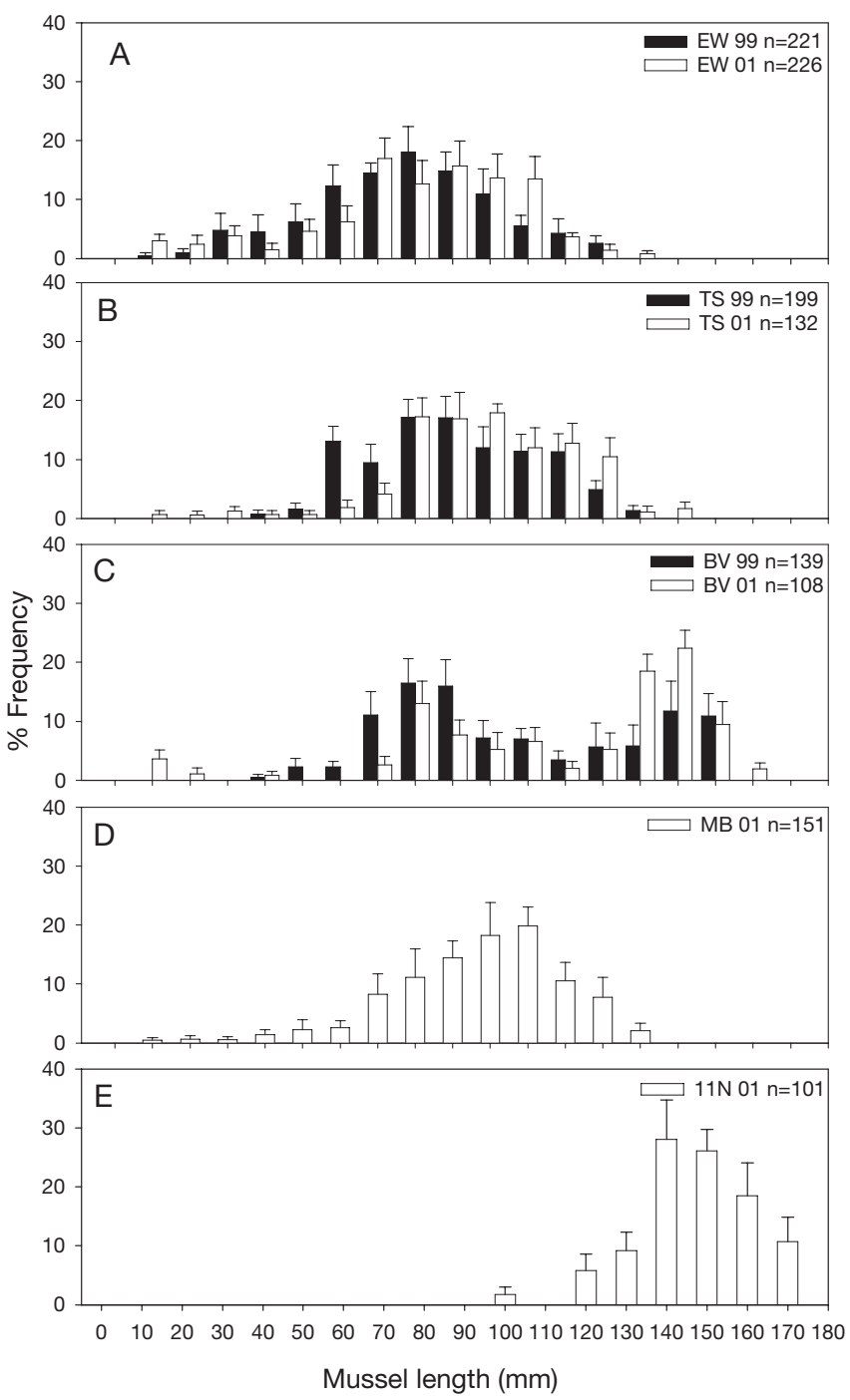

Fig. 2. Mussel size frequency distributions (mean $\%+$ SE, for mussels $>5 \mathrm{~mm}$ ) in quantitative samples from (A) EW, (B) TS and (C) BV in 1999 and 2001, and from (D) MB and (E) $11 \mathrm{~N}$ in 2001. $\mathrm{n}=$ total number of individuals measured

of the mussels collected from this bed in 2001 were $<90 \mathrm{~mm}$ in shell length.

The mussel condition index for mussels sampled from the 2 younger sites (EW, TS) was significantly greater in 2001 than in 1999 (ANCOVA, p < 0.001; Fig. $3 \mathrm{~A}, \mathrm{~B}$ ), but there was no significant betweensampling period difference observed in mussels from the older site (BV; ANCOVA, $\mathrm{p}=0.70$; Fig. 3C).

Slopes of $\mathrm{MB}$ and $11 \mathrm{~N}$ log-transformed weightlength relationships in mussels sampled in 2001 differed from those of the 2001 mussel samples from EW, TS, and BV and from one another (Fig. 3D). Data points for $\mathrm{MB}$ and $11 \mathrm{~N}$ mussels fell within the range of values observed in the EW, TS, and BV samples, sug-

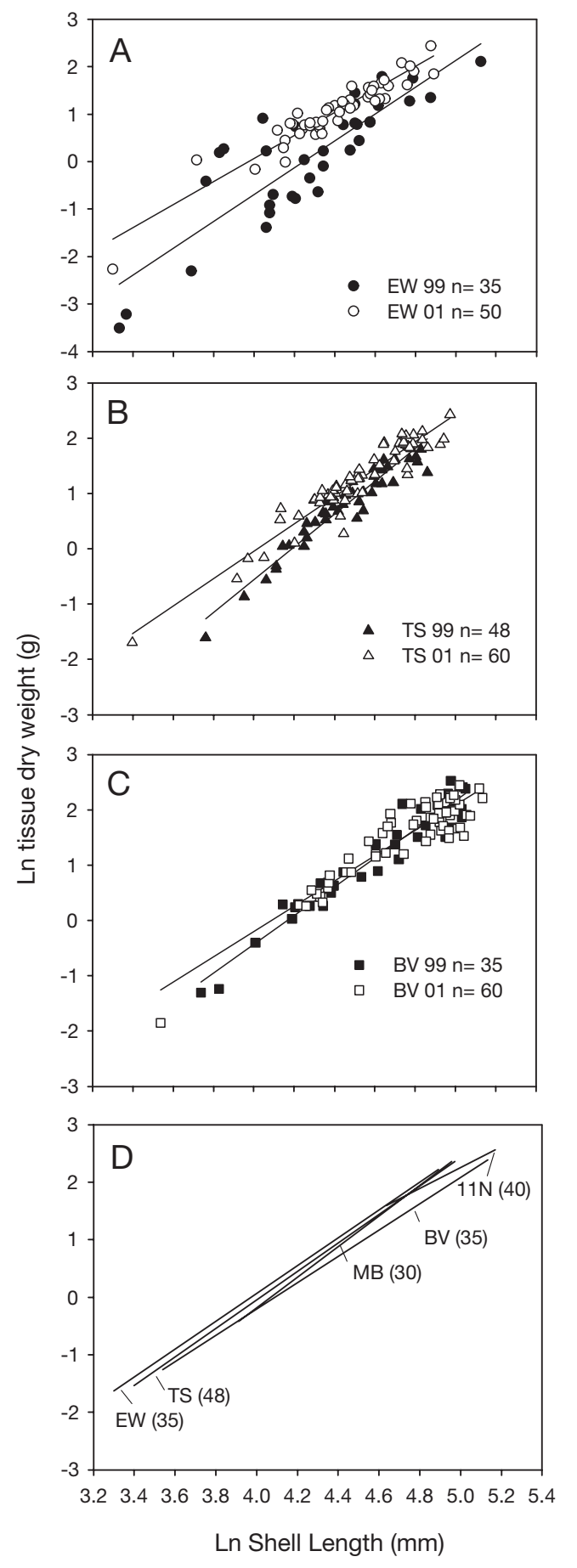

Fig. 3. (A-C) Ln tissue dry weight (g) versus Ln shell length $(\mathrm{mm})$ with regression lines for mussels in quantitative samples, 1999 and 2001. (A) EW, (B) TS, and (C) BV. (D) Regression lines for mussels in quantitative samples from the 5 chronosequence mussel beds in 2001; samples sizes in parentheses

gesting that there was no degradation or enhancement of mussel condition at the 2 oldest sites compared to the younger sites. 


\section{Time-series changes in community structure at EW, TS, and BV between 1999 and 2001}

There was no significant difference in the mean abundance of invertebrates associated with mussel beds between 1999 and 2001 sampling periods for EW or BV ( $t$-test, $\mathrm{p}>0.10$ ), but mean abundance decreased at TS ( $t$-test, $\mathrm{p}=0.03$; Table 1$)$. Six species accounted for $>95 \%$ of the total number of individuals in the invertebrate community associated with EW, TS, and BV mussel beds (Fig. 4). The top dominant species at all mussel beds in 1999 and in 2001 was the limpet, Lepetodrilus elevatus ( $>42 \%$ of individuals on average). The amphipod Ventiella sulfuris was the second most dominant species ( $>20 \%$ of all individuals on average) at EW and TS in 1999 and 2001, but accounted for $<1 \%$ of all individuals on average at BV in both years. The second most dominant species at BV was the ampharetid polychaete Amphisamytha galapagensis. All other top ranked species each contributed on average $<15 \%$ to the total abundance (Fig. 4). The composition of the top ranked species was similar at all 3 of the sites, though their rank order differed (Fig. 4). Singletons (taxa represented by a single individual in the entire sampling effort at a mussel bed in a given year) made up 8 to $16 \%$ of the invertebrate species in 1999 and in 2001, with the exception of BV in 2001, where only $5 \%$ of the species were singletons.

Mean biovolume of invertebrates sampled from mussel beds decreased between 1999 and 2001 at TS $(t$-test, $\mathrm{p}<0.05)$ and BV ( $t$-test, $\mathrm{p}=0.02$; Table 1 ). Mean biovolume also decreased between 1999 and 2001 at EW, but the difference was not significant. Two species accounted for $\sim 80$ to $90 \%$ of the total biovolume in these mussel beds (Fig. 5). Lepetodrilus elevatus was the biovolume dominant species at all sites, contributing to $>47 \%$ of the total biovolume on average (Fig. 5). The second ranked biovolume spe-

Table 1. Mean abundance and biovolume $( \pm \mathrm{SE})$ per liter of mussels sampled

\begin{tabular}{|lcc|}
\hline Mussel bed & $\begin{array}{c}\text { Abundance } \\
\text { (ind. } \mathrm{I}^{-1} \text { mussels } \\
\text { sampled) }\end{array}$ & $\begin{array}{c}\text { Biovolume } \\
\text { (ml l-1 mussels } \\
\text { sampled) }\end{array}$ \\
\hline East Wall 1999 & $737(229)$ & $8.0(1.4)$ \\
East Wall 2001 & $772(115)$ & $4.8(0.5)$ \\
Train Station 1999 & $969(59)$ & $6.7(0.6)$ \\
Train Station 2001 & $684(118)$ & $3.8(0.8)$ \\
Biovent 1999 & $810(214)$ & $6.7(1.4)$ \\
Biovent 2001 & $464(34)$ & $2.5(0.6)$ \\
Mussel Bed 2001 & $199(28)$ & $2.6(0.8)$ \\
11N 2001 & $429(64)$ & $1.4(0.4)$ \\
\hline
\end{tabular}
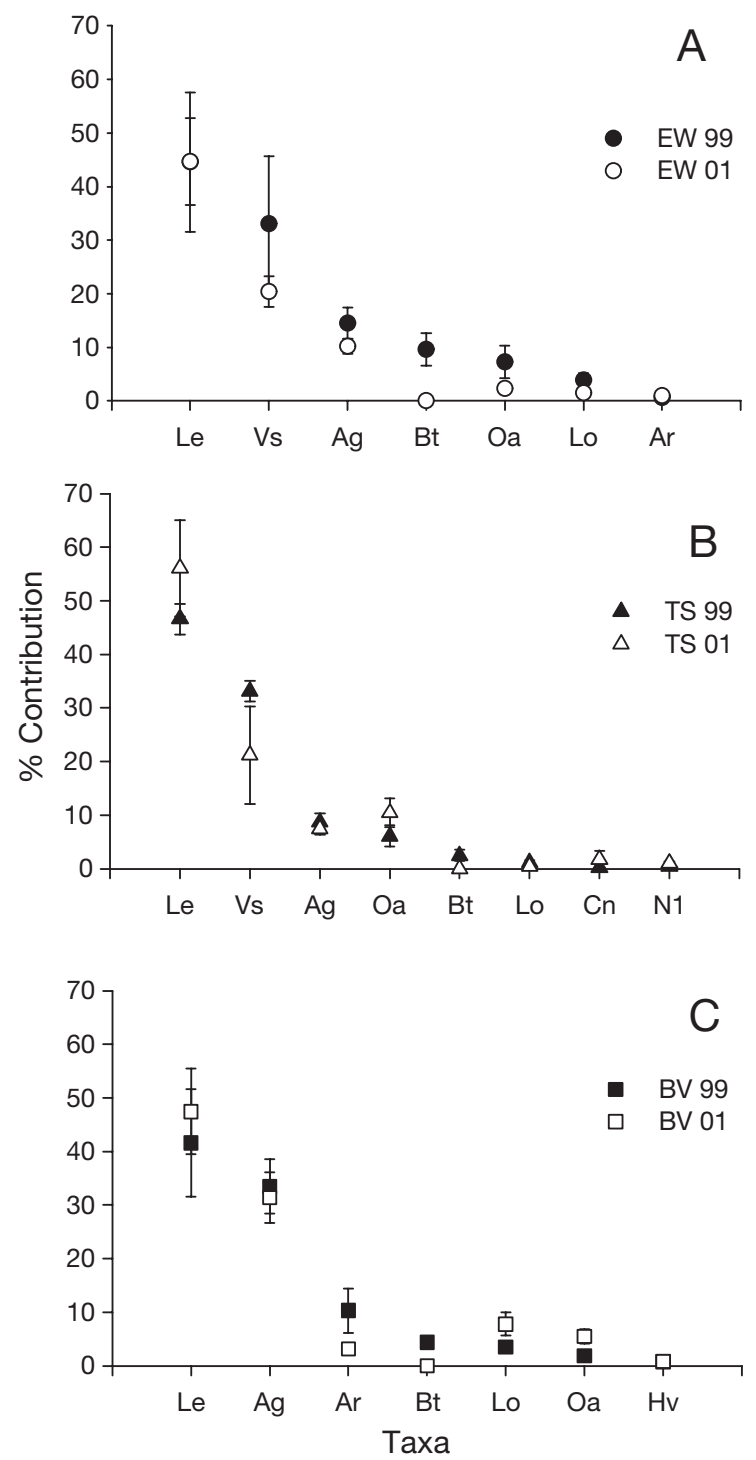

Fig. 4. Rank order of numerically dominant taxa at 9N EPR mussel beds (1999 and 2001). (A) EW, (B) TS, and (C) BV. Data points represent mean $\%$ abundance $( \pm \mathrm{SE})$ of individuals $1^{-1}$ mussel volume sampled. Ag: Amphisamytha galapagensis; Ar: Archinome rosacea; Bt: Bathymodiolus thermophilus $<5 \mathrm{~mm}$; Cn: Cyathermia naticoides; Hv: Hesiospina vestimentifera; Le: Lepetodrilus elevatus; Lo: Lepetodrilus ovalis; N1: Nemertea sp. 1; Oa: Ophryotrocha akessoni; Vs: Ventiella sulfuris

cies was more variable between sampling periods and among sites (Fig. 5).

The total number of species sampled from the time series mussel beds (Table 2) ranged from 31 (TS 1999) to 43 (BV 2001). For a given sampling effort, where effort is expressed in cumulative number of individuals sampled (Fig. 6A), species richness decreased between 1999 and 2001 at EW ( $S_{11000}=37$ to 34 species $)_{i}$ species richness increased in TS samples $\left(S_{15000}=24\right.$ to 37$)$ and 

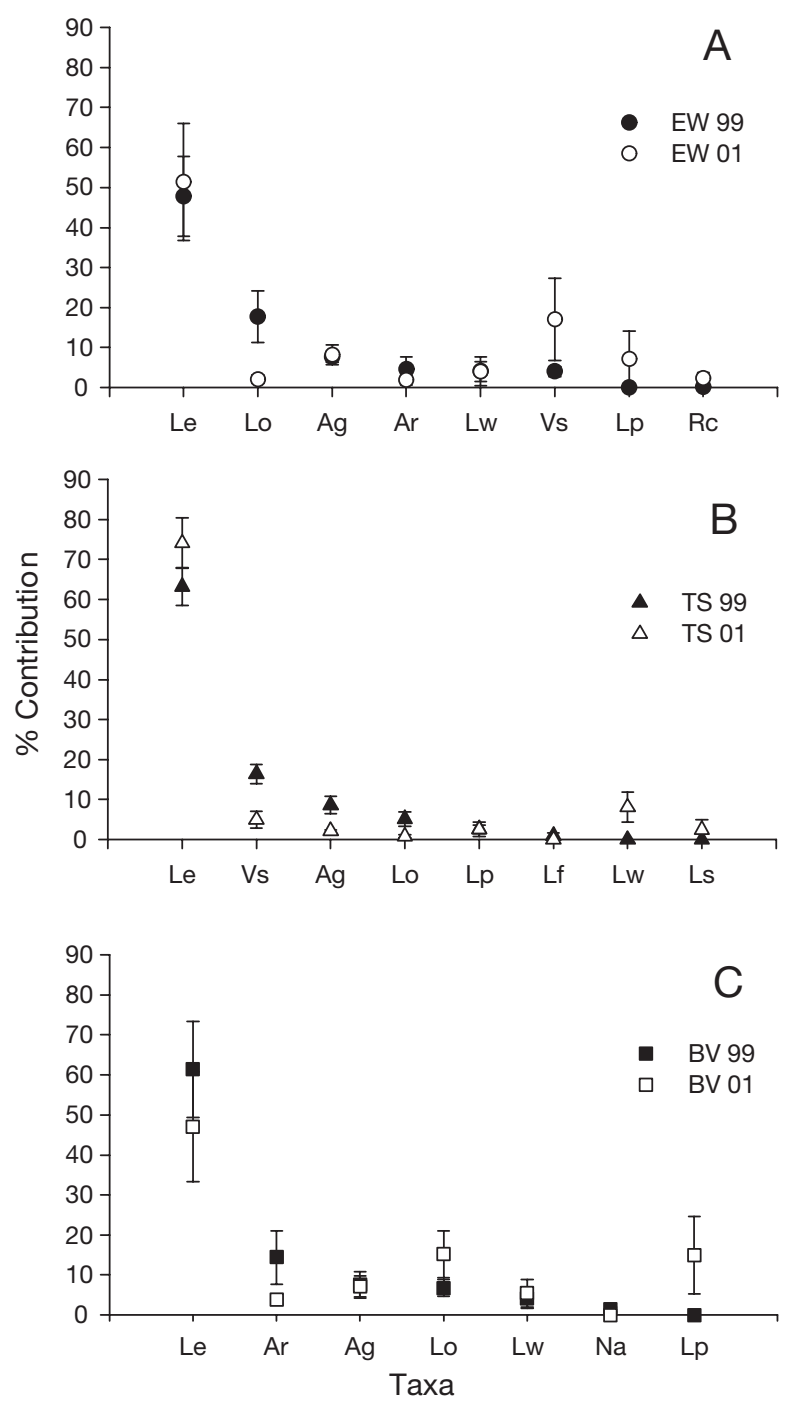

Fig. 5. Rank order of volumetrically dominant taxa at 9N EPR mussel beds (1999 and 2001). (A) EW, (B) TS and (C) BV. Data points represent mean $\%$ biovolume $( \pm \mathrm{SE}) \mathrm{ml} \mathrm{l}^{-1}$ mussel volume sampled. Ag: Amphisamytha galapagensis; Ar: Archinome rosacea; Le: Lepetodrilus elevatus; Lo: Lepetodrilus ovalis; Lp: Lepetodrilus pustulosus; Lf: Lepidonotopodium fimbriatum; Ls: Levensteiniella plicata; Lw: Lepidonotopodium williamsae; Rc: Rhynchopelta concentrica; Na: Nereimyra alvinae; Vs: Ventiella sulfuris

in BV samples $\left(S_{10000}=38\right.$ to 43$)$. Species effort curves based on the volume of mussels sampled as the measure of effort (= species density; Fig. 6B) indicate that one additional increment of sampling effort might add 2 or fewer rare species to the species list for each mussel bed.

There was no significant difference between mean diversity $\left(H^{\prime}\right)$, evenness $\left(J^{\prime}\right)$, and Fisher's $\alpha$ indices (Table 2) within quantitative samples for each site pair between 1999 and 2001, with the exception of a decrease in evenness $\left(J^{\prime}\right)$ at EW in $2001(\mathrm{p}=0.04)$.

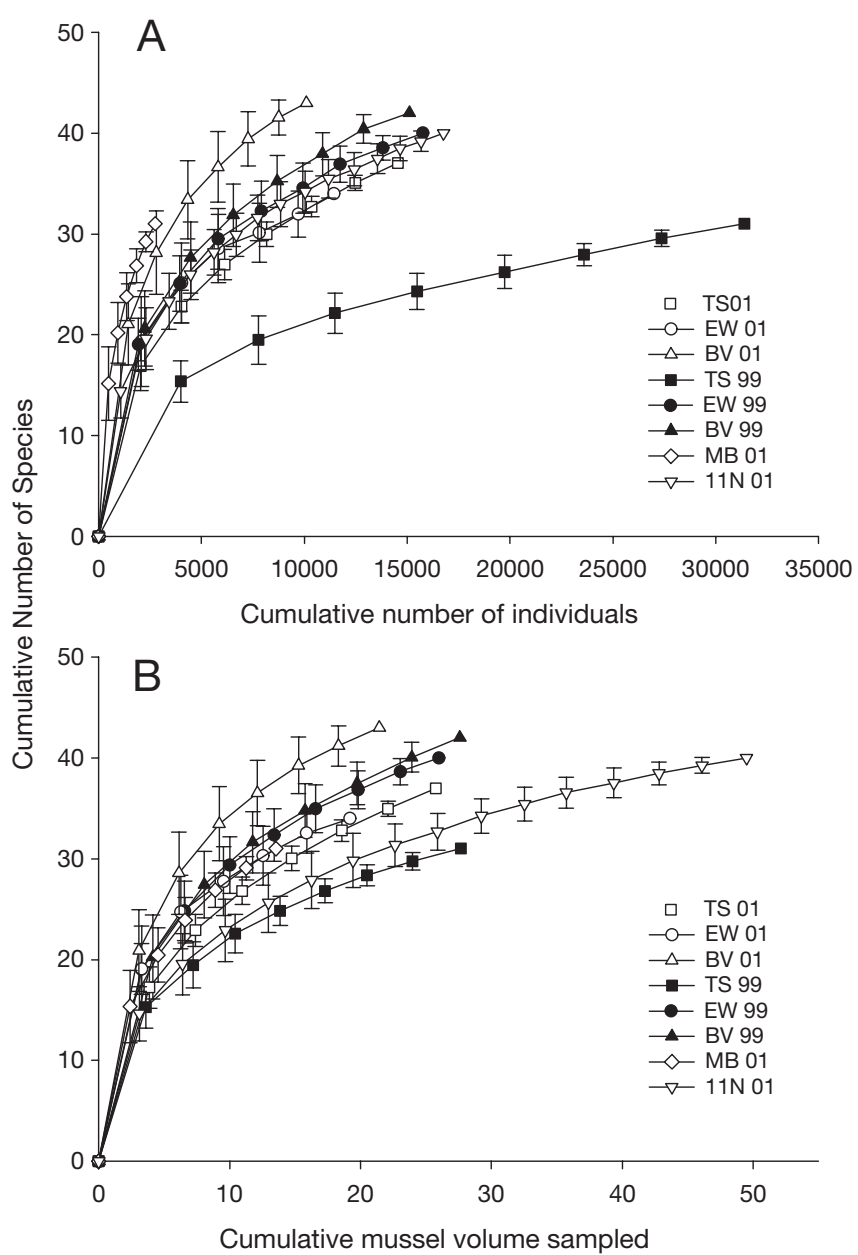

Fig. 6. Sample based species effort curves for EW, TS, BV (1999, 2001), MB (2001), and 11N (2001). (A) Species richness: effort based on cumulative number of individuals. (B) Species density: effort based on cumulative sample volume (l) of mussels. Data points are means \pm SD (randomizations $=100$, without replacement)

Approximately half (51 to $57 \%$ ) of the total number of species collected from a given mussel bed were found in both 1999 and 2001 samples. Only 20 to $30 \%$ of species were shared between pairs of mussel beds in 2001 .

Changes in community structure of macrofauna associated with mussel beds at EW, TS, and BV between 1999 and 2001 could be detected using MDS and analysis of similarity (i.e. $\mathrm{R}>0.4$ ) based on square-root transformed species abundance matrices (Fig. 7A). Species contributing most to the temporal changes (e.g. Lepetodrilus elevatus, Ventiella sulfuris, among others; Table 3) showed no consistent pattern of increase or decrease in average abundance between years, with the exception of juvenile mussels, which, as mentioned above, were nearly absent in the 2001 samples from all sites. 
Biovolume of macrofauna associated with EW and BV mussel bed samples from 1999 and 2001 were not well separated based on the MDS analysis of the species biovolume matrix $(\mathrm{R}=0.17)$, but there was a shift

Table 2. Number of samples (N), total abundance (n), species richness $(S), H^{\prime}$ log e $( \pm \mathrm{SE}), J^{\prime}( \pm \mathrm{SE})$, and Fisher's $\alpha( \pm \mathrm{SE})$ on sample based data standardized per liter of mussel volume sampled for mussel beds at $9 \mathrm{~N}$ in 1999 and 2001, and at the $11 \mathrm{~N}$ mussel bed in 2001

\begin{tabular}{|lcrcccc|}
\hline Location & $\mathrm{N}$ & $\mathrm{n}$ & $S$ & $H^{\prime}$ log e & $J^{\prime}$ & Fisher's $\alpha$ \\
\hline 9N 1999 & & & & & & \\
East Wall & 6 & 15758 & 40 & $1.59(0.17)$ & $0.57(0.03)$ & $3.41(0.27)$ \\
Train Station & 6 & 31401 & 31 & $1.36(0.04)$ & $0.48(0.03)$ & $2.77(0.18)$ \\
Biovent & 5 & 15116 & 42 & $1.42(0.13)$ & $0.47(0.04)$ & $4.20(0.60)$ \\
9N 2001 & & & & & & \\
East Wall & 5 & 11426 & 34 & $1.15(0.11)$ & $0.40(0.03)$ & $3.44(0.42)$ \\
Train Station & 5 & 14557 & 37 & $1.18(0.11)$ & $0.42(0.05)$ & $3.21(0.33)$ \\
Biovent & 6 & 10103 & 43 & $1.32(0.14)$ & $0.45(0.05)$ & $4.29(0.45)$ \\
Mussel Bed & 6 & 2754 & 31 & $1.93(0.05)$ & $0.73(0.03)$ & $3.76(0.40)$ \\
11N 2001 & 12 & 16769 & 40 & $1.33(0.05)$ & $0.50(0.02)$ & $2.99(0.25)$ \\
\hline
\end{tabular}

Table 3. Contributions of abundance dominant species and biovolume dominant macrofaunal species (average no. ind. [or ml] $\mathrm{l}^{-1}$ mussel volume sampled, \% contribution, and cumulative \% contribution) to dissimilarities between samples from mussel beds collected in 1999 and 2001. Analyses are based on species abundance or species biovolume matrices (standardized per 1 of mussel volume sampled and square-root transformed)

\begin{tabular}{|c|c|c|c|c|}
\hline & \multicolumn{2}{|c|}{ Average } & \multicolumn{2}{|c|}{ Contribution to dissimilarity } \\
\hline & 1999 & 2001 & $\begin{array}{c}\text { Contribution } \\
(\%)\end{array}$ & $\begin{array}{c}\text { Cumulative } \\
(\%)\end{array}$ \\
\hline \multicolumn{5}{|l|}{ Abundance } \\
\hline \multicolumn{5}{|l|}{ East Wall } \\
\hline Lepetodrilus elevatus & 305 & 355 & 16.8 & 16.8 \\
\hline Ventiella sulfuris & 150 & 264 & 15.3 & 32.1 \\
\hline Bathymodiolus thermophilus $<5 \mathrm{~mm}$ & 60 & 1 & 13.8 & 45.9 \\
\hline Ophryotrocha akessoni & 61 & 16 & 7.1 & 53.0 \\
\hline Amphisamytha galapagensis & 59 & 102 & 6.2 & 59.1 \\
\hline \multicolumn{5}{|l|}{ Train Station } \\
\hline Ventiella sulfuris & 334 & 166 & 22.3 & 22.3 \\
\hline Bathymodiolus thermophilus $<5 \mathrm{~mm}$ & 25 & 0 & 11.4 & 33.7 \\
\hline Lepetodrilus elevatus & 468 & 354 & 9.5 & 43.2 \\
\hline Ophryotrocha akessoni & 57 & 79 & 9.2 & 52.4 \\
\hline Amphisamytha galapagensis & 86 & 47 & 6.3 & 58.6 \\
\hline Cyathermia naticoides & 2 & 18 & 5.6 & 64.3 \\
\hline \multicolumn{5}{|l|}{ Biovent } \\
\hline Lepetodrilus elevatus & 391 & 220 & 17.4 & 17.4 \\
\hline Bathymodiolus thermophilus $<5 \mathrm{~mm}$ & 34 & 0 & 12.3 & 29.7 \\
\hline Archinome rosacea & 60 & 13 & 9.3 & 39.0 \\
\hline Amphisamytha galapagensis & 244 & 133 & 8.7 & 47.6 \\
\hline Ophryotrocha akessoni & 21 & 25 & 6.7 & 54.3 \\
\hline Lepetodrilus ovalis & 24 & 33 & 5.5 & 59.8 \\
\hline \multicolumn{5}{|l|}{ Biovolume } \\
\hline \multicolumn{5}{|l|}{ Train Station } \\
\hline Ventiella sulfuris & 1.0 & 0.2 & 17.3 & 17.3 \\
\hline Lepetodrilus elevatus & 3.9 & 2.7 & 12.2 & 29.5 \\
\hline Amphisamytha galapagensis & 0.6 & 0.1 & 11.9 & 41.4 \\
\hline Lepidonotopodium williamsae & 0.0 & 0.3 & 10.8 & 52.1 \\
\hline Lepetodrilus ovalis & 0.3 & 0.0 & 10.6 & 62.7 \\
\hline
\end{tabular}

\section{Chronosequence comparisons of community structure}

There were fewer individuals per liter of mussels sampled (on average) in 2001 at the older (BV, MB, $11 \mathrm{~N})$ mussel beds than at the younger mussel beds (EW, TS; Table 1). There was no significant relationship between mean abundance and mussel bed age (Fig. 8A; regression, $p=0.25$ ), but mean biovolume decreased with increasing mussel bed age (Fig. 8B; regression, $\mathrm{p}<0.001$ ).

The most species rich samples in the chronosequence comparison (Fig. 6A) were from MB. In order of decreasing species richness $\left(S_{2700}\right)$, the chronosequence samples ranked as: MB 31 species > BV 28 species $>11 \mathrm{~N} 20$ species $>$ EW 19 species $>$ TS 17 species. For the $9 \mathrm{~N}$ sites, the older sites thus had 1.5 times more species than the younger sites. When comparing species density (where sampling effort is standardized to mussel volume), the hierarchy of species density (Fig. 6B) for a given sampling effort $\left(S_{141}\right)$ in 2001 was BV 39 species > MB and EW 31 species > TS 30 species $>11 \mathrm{~N}$ 26 species.

Mean diversity $\left(H^{\prime}\right)$ and evenness $\left(J^{\prime}\right)$ indices for samples from chronosequence mussel beds (Table 2) differed significantly by mussel bed (ANOVA, df $=33, F\left(H^{\prime}\right)=12.73$, $\left.F\left(J^{\prime}\right)=16.24 ; \mathrm{p}<0.001\right)$, but there were no significant differences in Fisher's $\alpha$ among samples (ANOVA, $\mathrm{df}=33, F=2.35 ; \mathrm{p}=0.08)$. The fauna in samples from MB was significantly more diverse $\left(H^{\prime}\right)$ and 

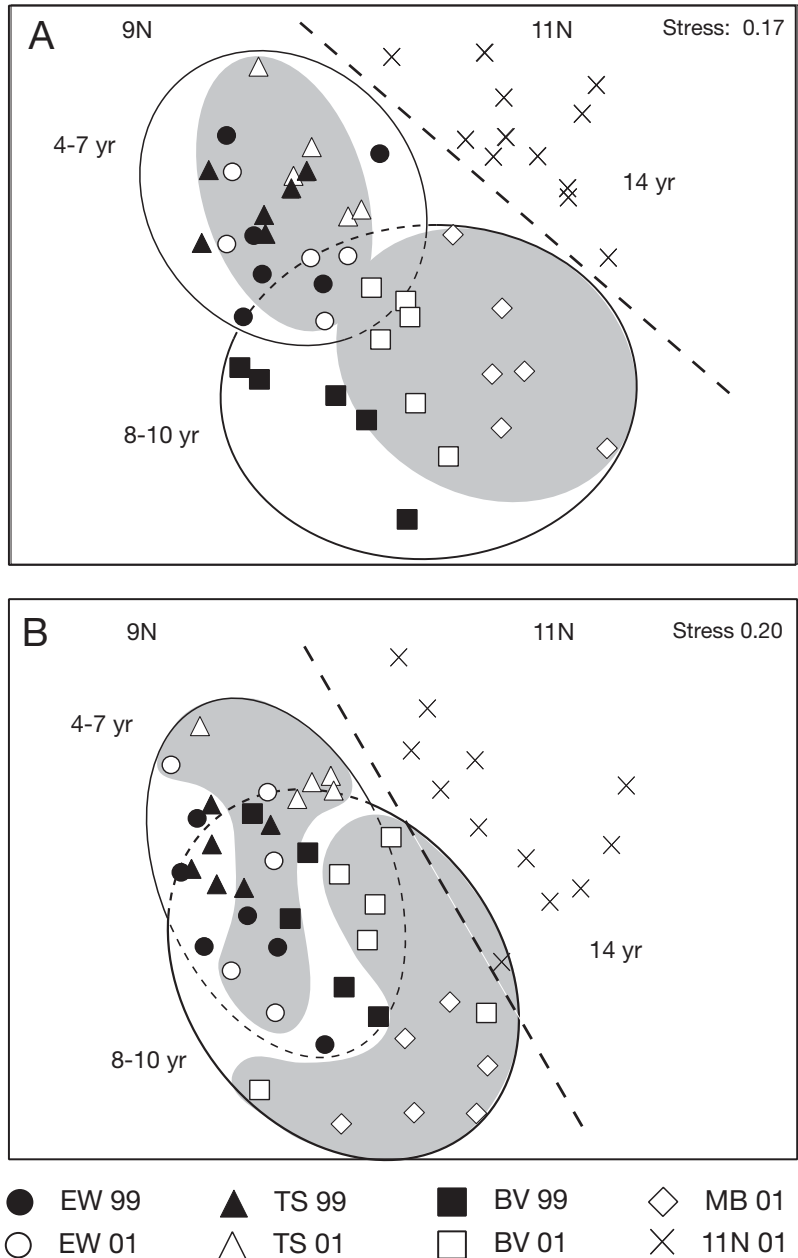

Fig. 7. Multidimensional scaling (MDS) plots of macrofaunal community structure in quantitative samples from mussel beds at EW, TS, BV (9N) in 1999 and 2001, and from MB (9N) and $11 \mathrm{~N}$ sites in 2001. (A) MDS plot based on standardized, squareroot-transformed, standardized abundance biovolume (ind. $\mathrm{l}^{-1}$ mussel volume sampled) data. (B) MDS plot based on squareroot-transformed, standardized biovolume $\left(\mathrm{ml} \mathrm{l}^{-1}\right.$ mussel volume sampled) data. Dashed lines highlight the separation between $11 \mathrm{~N}$ samples (above) and 9N samples (below); ovals embrace samples from mussel beds in the 4 to 7 yr age group and in the 8 to $10 \mathrm{yr}$ age group; shaded areas embrace the 2001 samples for the 4 to $7 \mathrm{yr}$ and 8 to $10 \mathrm{yr}$ age groups

species were significantly more evenly distributed $\left(J^{\prime}\right)$ compared to the invertebrates collected in samples from other sites (Tukey's multiple comparisons test).

Samples from the oldest mussel bed (11N) clustered separately from the $20019 \mathrm{~N}$ samples in both species abundance $(\mathrm{R}=0.60)$ and species biovolume $(\mathrm{R}=0.40)$ multivariate comparisons (Fig. 7). The greatest contributions to the species abundance differences between $11 \mathrm{~N}$ and $9 \mathrm{~N}$ samples were due to higher densities of Ophryotrocha akessoni and lower densities of Lepetodrilus elevatus and Ventiella sulfuris at $11 \mathrm{~N}$ (Table 4A).
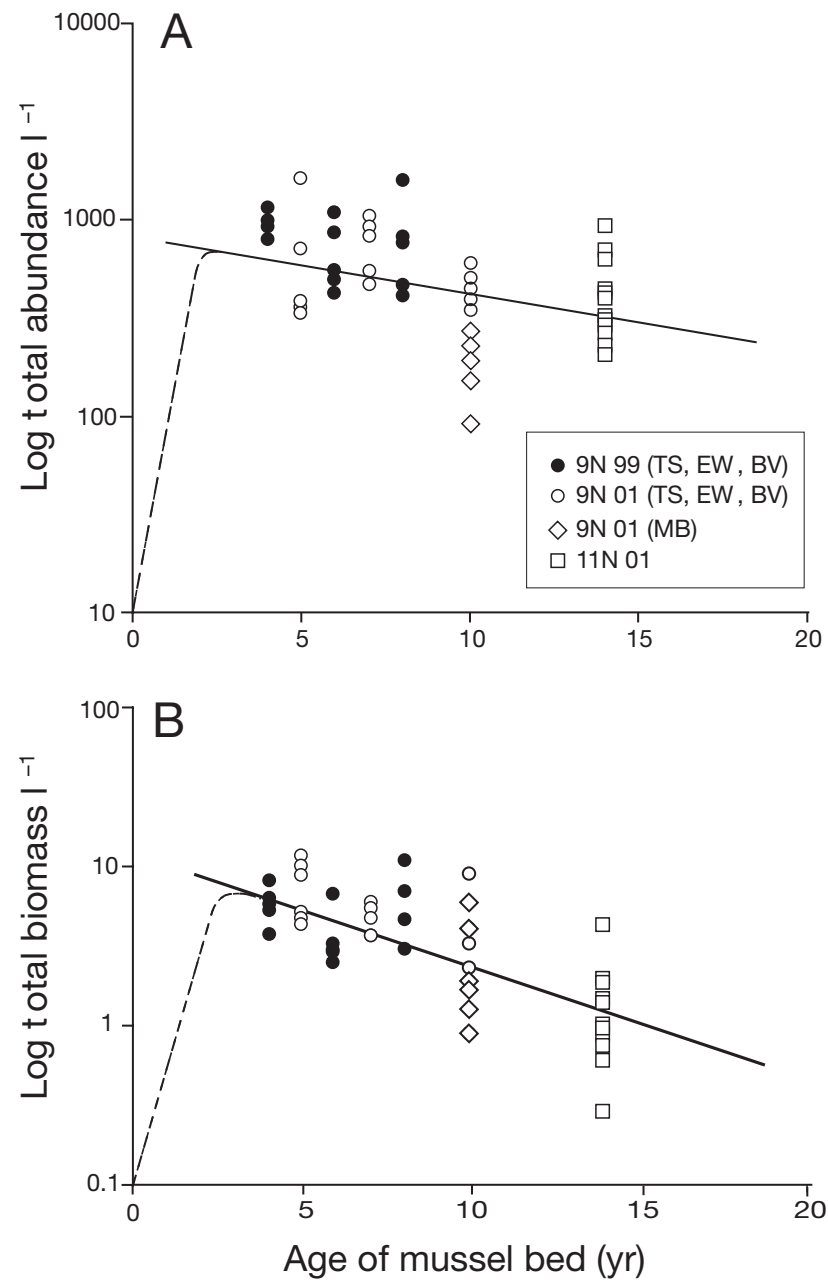

Fig. 8. (A) Abundance and (B) biovolume of macrofauna associated with mussel beds versus estimated age of mussel beds based on chronosequence samples from the northern EPR. Each symbol represents one quantitative sample. The dashed lines represent a model of the increase in abundance or biovolume of associated macrofauna as a mussel bed develops; solid lines are regressions of mean abundance or biovolume versus mussel bed age for the chronosequence samples from $9 \mathrm{~N}$ and $11 \mathrm{~N}$ collected in 2001

The low biovolume of $L$. elevatus at $11 \mathrm{~N}$ was the largest contributor to differences between $11 \mathrm{~N}$ and $9 \mathrm{~N}$ in the MDS analysis of the species biovolume matrix (Table 4A).

The 4 sets of mussel bed samples from 9N in 2001 clustered into 2 age groups: 'younger' (EW, TS) and 'older' (BV, MB) based on the species abundance matrix $(\mathrm{R}=0.50)$ and the species biovolume matrix $(\mathrm{R}=$ 0.47). Average abundances of Ventiella sulfuris and Lepetodrilus elevatus were lower in the older sites, each species contributing to about $20 \%$ of the dissimilarity (Table $4 \mathrm{~B}$ ). As in the comparison between $11 \mathrm{~N}$ and $9 \mathrm{~N}$ mussel beds, dissimilarities in biovolume in 
samples from younger and older mussel beds were driven largely by the low biovolume of L. elevatus at the older mussel beds (Table 4B).

\section{DISCUSSION}

Patterns in community structure through space and time are fundamental attributes of marine ecosystems that allow ecologists to develop and test hypotheses about the ecological processes underlying the patterns (Underwood et al. 2000). Patterns and processes occurring in the rocky intertidal, where many studies of community structure and ecological processes in marine systems have been undertaken (reviewed in Menge \& Branch 2001), may not necessarily have the same importance in deep-sea chemosynthetic ecosystems, especially given differences in seasonality, hydrographic regimes, and other physical factors that distinguish these 2 environments. Results from this study suggest that the short term (inter-annual) and local heterogeneity in community structure often associated with disturbance regimes and colonization by pelagic larvae (reviewed in Sousa 2001) is not evident in the macrofaunal community associated with established mussel beds at hydrothermal vents on the EPR. In this discussion, we summarize the development of community structure in these mussel beds during the hydrothermal cycle. We then highlight the spatially and temporally predictable nature of the dominant species in this community, and we consider reasons why 2 important attributes of community structure-abundance and biovolume - might decline as mussel beds age.

\section{Macrofaunal community development in mussel beds at hydrothermal vents on the EPR}

From the combination of time series sampling (this study) and chronosequence results (Van Dover 2002a, 2003, this study), a description of the development of community structure in persistent mussel beds on the EPR is possible, even though the initial development of the macrofaunal community within mussel beds (i.e. 0 to $4 \mathrm{yr}$ ) remains undocumented. We deduce that biovolume and abundance increase from 0 to a maximum value within this early 0 to $4 \mathrm{yr}$ period, and that the rate of increase in species richness within the mussel bed habitat is steepest during this period as well.

Within 4 yr, Lepetodrilus elevatus becomes established as the dominant species within mussel beds. Limpets may colonize low temperature sites even before mussels arrive; limpets (including Lepetodrilus elevatus) were among the early colonists (within 1 yr) of persistent low temperature vent sites following the eruption at 9N (Shank et al. 1998). L. elevatus, the amphipod Ventiella sulfuris, the polychaetes Amphisamytha galapagensis, Ophryotrocha akessoni, and Archinome rosacea, and the limpet Lepetodrilus ovalis, represent the suite of top ranked species (especially in abundance) in mussel beds that are between 4 and 
$10 \mathrm{yr}$ old. With the exception of the micropredatory polychaete, Archinome rosacea (Ward et al. 2003), the trophic character of these top dominants is not well known; they are assumed to be grazers or deposit feeders, or possibly filter feeders in the case of the lepetodrilid limpets. Post-larvae and juvenile mussels periodically join the list of numerically dominant macrofaunal species, subject to delivery of larvae.

Between 4 and $10 \mathrm{yr}$, the dominant macrofaunal species within mussel beds and diversity remain essentially unchanged, but species richness continues to increase gradually as more rare or uncommon species are added to the community. Macrofaunal community structure in mussel beds that are 4 to $7 \mathrm{yr}$ old are difficult to distinguish from one another. Macrofaunal abundance and biovolume are variable within a mussel bed (Van Dover 2003; this study), but on average, they decline with increasing mussel bed age.

The macrofaunal community associated with mussel beds that are $10 \mathrm{yr}$ or more in age has a significantly lower biovolume compared to the community in younger mussel beds. The composition of the suite of dominant species also begins to shift (e.g. Ventiella sulfuris becomes less important, Dahlella caldariensis [leptostracan] densities increase).

When hydrothermal activity in a mature mussel bed ceases, mussel condition declines dramatically, gill tissues of mussels become aposymbiotic, mussel mortality becomes patent (Raulfs et al. 2004), and the abundance of the associated macrofauna drops precipitously (Van Dover 2002a, this study). The composition of the macrofaunal community changes dramatically (Lepetodrilus elevatus disappears from the community, non-endemic species from the surrounding deep sea invade) and biovolume becomes dominated by large scavenging polychaetes (Van Dover 2002a).

Macrofaunal community development in mussel beds on the EPR thus appears to be very different from the dynamic changes observed in macrofaunal community structure associated with sulfide chimneys at vents in the NE Pacific, where frequent disturbance and modification of habitat conditions favor shifting suites of dominant species on local scales $(10 \mathrm{~s}$ of $\mathrm{cm})$ over relatively short time periods (sub-annual; Sarrazin et al. 1997, Sarrazin \& Juniper 1999). This perceived difference may reflect different scales of observation and sampling that are relevant for NE Pacific and EPR vent communities. At the scale of a ridge segment, invertebrate community structure associated with 'mature' tubeworm clumps ( $\geq 3$ yr) is very similar (Tsurumi \& Tunnicliffe 2001). At the decimeter scale within a mussel bed, there will almost certainly be shifting suites of dominant species as the local environmental milieu is modified by shifts in position of mussels or other factors.

\section{Why should the dominant macrofaunal species in vent mussel beds on the EPR be so monotonous?}

Community ecologists have come to view community assemblages in marine systems as dynamic mosaics of species whose patchiness results from disturbance (reviewed in Sousa 2001), with transitory changes in species composition and abundance within a climax community reflecting differences in recruitment, growth, persistence, and rate of replacement among species following disturbance (Tanner et al. 1994). In rocky intertidal mussel beds, major temporal and spatial variations in diversity and abundance of associated macrofauna have been attributed to the stochastic nature of mortality and are linked to planktonic larval dispersal and settlement (Seed 1996). Where disturbance is weak or absent, dynamic mosaics may also be absent (or difficult to detect), as documented by Foster et al. (2003) for an algal dominated, high intertidal assemblage.

There is little evidence for dynamic mosaics of invertebrate species in mature mussel beds on the EPR, at least in terms of the composition of the dominant taxa. The suite of dominant macrofaunal species at $9 \mathrm{~N}$ mussel beds is also dominant at $11 \mathrm{~N}$ mussel beds and at mussel beds far removed, i.e. at 18S (Southern East Pacific Rise) on the EPR (Van Dover 2002a, 2003). Although the rank order of the dominant species includes some variability, the overall view is one of a surprisingly monotonous assemblage. Carney (1995; cited in Bergquist et al. 2003) reports a similarly monotonous macrofaunal assemblage within mussel beds at seeps in the Gulf of Mexico.

The emphasis for community assembly rules within mature mussel beds on the EPR thus shifts from factors that result in variation to factors that result in predictability over large distances (e.g. $9 \mathrm{~N}$ to $11 \mathrm{~N}$ ) and variations in age ( 4 to $15 \mathrm{yr}$ ) and other habitat characteristics. This is the hydrothermal vent analogue to the 'equilibrium' tropical tree community of Terborgh et al. (1996). The predictability of the dominant species within mussel beds on the EPR does not imply that variable recruitment and a variety of biological interactions (positive and negative) are not taking place in mussel beds. Size frequency distributions of dominant macrofaunal species (C. L. Van Dover \& J. C. Dreyer unpubl. data), for example, suggest that there may be large variations in recruitment levels among mussel beds and between sampling periods. Instead, the dominant species in established mussel beds appear to be those species enjoying some combination of life history and physiological attributes that allow them to recruit to and survive in mussel beds with greater success than other species. Lepetodrilid limpets are especially notable in this regard, as representatives of the genus 
Lepetodrilus are numerical dominants within macrofaunal communities of Juan de Fuca (Tsurumi \& Tunnicliffe 2003) and EPR vent habitats.

Why should the limpet, Lepetodrilus elevatus, always be the numerical dominant, and the amphipod, Ventiella sulfuris, often be a close second? The answers are elusive, in large part because, despite recent progress in understanding larval development in a few vent species (e.g. Marsh et al. 2001, Pradillon et al. 2001), we do not yet understand how local populations of any species at vents are maintained and so we do not know how to assess the fitness advantage of the common species. Initial colonists must arrive at new vents from distant brood stocks, but could local populations of the most common species be self-sustaining once initial colonization has taken place (especially in those species with lecithotrophic or direct development)? We also do not have a complete understanding of the trophic capabilities within and interactions among many species. While L. elevatus is assumed here to be a grazer (and possibly a filter-feeder), if it also hosted episymbionts from which it derives some or most of its nutrition, as has been suggested for its congener ( $L$. fucensis) of Juan de Fuca vents (Fox et al. 2002), it might be expected to have a competitive advantage over species that rely only on grazing. Relatively small changes in fitness can produce large differences in steady state relative species abundances within models that incorporate neutral theory and ecological drift (Hubbell 2001). Patterns of relative abundance in vent ecosystems may prove to be useful as mixed models (sensu Hubbell 2001) in which a few species are competitive dominants that express a hierarchy of relative fitness and that secure most of the resources while the rest of the species are gleaners that compete for leftovers in a more competitively neutral zero sum game.

\section{Why does macrofaunal biovolume decrease with age of a mussel bed?}

The most dramatic, systematic differences in community structure observed within mussel beds are the decreasing abundance and especially biovolume of macrofaunal invertebrates with increasing age of the mussel beds. One explanation for this pattern might be a decrease in hydrothermal activity with increasing age of a mussel bed, i.e. a decrease in the delivery of inorganic nutrients to support the microbial production that in turn supports the macrofauna. Waning or dramatically changing hydrothermal chemistry has been shown to be important in effecting changes in megafaunal distributions at $9 \mathrm{~N}$ vents (Shank et al. 1998). Reliable long term measures of hydrothermal flux and chemistry in mussel beds are not readily obtained, however. Point measures of temperature and chemistry in space and time are notoriously difficult to interpret, given the turbulent flow of warm waters and complex mixing regimes within a mussel bed (Johnson et al. 1994). Mussel condition arguably provides one of the most robust, integrative measures of hydrothermal activity available. When hydrothermal activity ceases, mussel condition (as indexed by tissue dry weight vs. shell length) deteriorates and gill tissues become aposymbiotic (Raulfs et al. 2004). There was no evidence of deteriorating mussel condition with age of a mussel bed in this study, suggesting that there was no major decline in hydrothermal activity at the older sites, at least to a first order approximation.

An alternative hypothesis could account for decreased macrofaunal biovolume without requiring a diminution of the fluid flux: availability of inorganic nutrients (especially dissolved sulfide) to the free living microorganisms on which the macrofaunal invertebrates depend (Van Dover \& Fry 1994, Van Dover 2002b) was substantially decreased due to the efficiency with which the endosymbiont populations of the mussels strip the water of sulfide. As the mussels grow, their gills increase in size, resulting in increased pumping capacity, larger symbiont populations, and greater demand for sulfide. Dense mytilid (Mytilus edulis) mussel beds can process more than $100 \mathrm{~m}^{3}$ seawater $\mathrm{m}^{-2}$ mussel bed ${ }^{-1} \mathrm{~d}^{-1}$ (Jorgensen 1990); dense bathymodiolin mussel beds probably at least match this rate. The increased demand for sulfide on the part of larger and larger symbiont populations must exist, if the mussels and their symbionts are to remain productive. The inferred consequence is that sulfide may become a limiting nutrient for free living microbial populations in older mussel beds. Less free living microbial biomass would result in lower abundances and biomass of invertebrates that depend on this biomass. The relative importance of competitive interaction between free living and endosymbiotic bacteria and its consequent 'bottom-up' effect (Menge \& Branch 2001) on invertebrate community structure in vent mussel beds remains to be determined, but it certainly seems to be taking place at some level.

A third non-exclusive hypothesis to account for decreased abundance and biovolume of macrofauna associated with hydrothermal vent mussel beds on the EPR is ingestion of larvae by the mussels. As the mussels grow and continue to increase their capacity to move water across their gills, they may effectively remove larvae or even post-larvae of macrofaunal species from the water, either by binding them with mucus as pseudofeces or ingesting them. Removal of larvae has been documented for a variety of suspension feeding molluscs, including oysters (Tamburri \& Zimmer- 
Faust 1996) and mytilid mussels (Lehane \& Davenport 2002, 2004), and is important in structuring benthic communities (Woodin 1976). By this mechanism, recruitment success of macrofaunal invertebrates might decrease with increasing age of a mussel bed. As the resident macrofauna continue to suffer mortality through predation or other causes, abundance and biovolume will drop. The absence of any mussels less than $90 \mathrm{~mm}$ at the $11 \mathrm{~N}$ mussel beds is consistent with larviphagy (i.e. cannibalism of larvae by adults; Timko 1979) by the adult mussel population, although this is by no means proof that such a process is on going.

Declining abundance and biovolume of invertebrates within chemosynthetic ecosystems, as the systems age, is not restricted to mussel bed communities at vents. Bergquist et al. (2003) note that at Gulf of Mexico seeps, invertebrate communities associated with tubewormmussel habitats are initially dense, with high biomass of seep endemic species. These authors also implicate mussel filtering activity in suppressing successful colonization within the tubeworm habitat. As tubeworms modify their environment and increase their demand for sulfide, sulfide availability to free living microorganisms decreases, the density and biomass of seep endemic species declines, and non-endemic species may invade (Bergquist et al. 2003). This model for community succession in the seep environment is presumed to take place over 100's of years (Bergquist et al. 2003), while a similar succession pattern in the vent environment occurs on a decadal time scale.

\section{CONCLUSION}

Once established, macrofaunal communities in mussel beds at hydrothermal vents on the EPR are relatively stable in terms of the species that are most abundant, that make up most of the macrofaunal biomass, and in terms of species rank abundance patterns, diversity and evenness indices. Total macrofaunal abundance and biovolume decrease as the mussel bed ages and species richness slowly increases as rare or uncommon species colonize the mussel bed. The dominant species appear to have a fitness advantage over other species in the community. In the absence of waning hydrothermal activity, the decrease in macrofaunal biovolume and abundance is likely caused by a combination of factors, including utilization of inorganic substrates by endosymbiotic bacteria in the host mussels and a consequent decrease in nutrients for free living microorganisms on which the macrofaunal community depends, inhibition of larval recruitment by mussels as they process water through their gills, and attrition of macrofaunal populations by predation. The relative importance of these processes remains unknown.
Acknowledgements. We thank the captain and crew of the RV 'Atlantis', the pilots and crew of the DSV 'Alvin', and the shipboard scientific parties for assistance in collecting and processing samples. We are grateful to M. Evans and A. Patel who helped us with sorting and measuring animals in the laboratory. Stephane Hourdez provided valuable taxonomic expertise, D. Evans, G. Gilchrist, and R. Seitz provided assistance with statistics. We appreciate reviews from R. Carney and 2 anonymous reviewers that improved the quality of the manuscript. This work was supported by the National Science Foundation (Biological Oceanography Program: OCE-988550, OCE-9982999) and by The College of William and Mary.

\section{LITERATURE CITED}

Bergquist DC, Ward T, Cordes EE, McNelis T and 5 others (2003) Community structure of vestimentiferan-generated habitat islands from Gulf of Mexico cold seeps. J Exp Mar Biol Ecol 289:197-222

Carney RS (1995) Sessile macrofauna and megafauna at mussel beds. Northern Gulf of Mexico chemosynthetic ecosystems final report. Prepared for Minerals Management Services under contract 14-35-0001-30555, p 25

Childress JJ, Fisher CR (1992) The biology of hydrothermal vent animals: Physiology, biochemistry, and autotrophic symbioses. Oceanogr Mar Biol Annu Rev 30:337-441

Clarke KR, Gorley RN (2001) PRIMER v5: User Manual/ Tutorial. PRIMER-E Ltd., Plymouth

Colwell, RK (1997) EstimateS: Statistical estimation of species richness and shared species from samples. Version 5. User's Guide and application published at: http://viceroy. eeb.uconn.edu/estimates

Copley JTP, Tyler PA, Van Dover CL, Schultz A, Dickson P, Singh S, Sulanowska M (1999) Subannual temporal variation in faunal distributions at the TAG hydrothermal mound (26 N, Mid-Atlantic Ridge). Mar Ecol 20:291-306

Crane K, Ballard RD (1980) The Galapagos Rift at 86² W: 4. Structure and morphology of hydrothermal fields and their relationship to volcanic and tectonic processes of the Rift Valley. J Geogr Res 85:1443-1454

Fiala-Médioni A (1984) Mise en évidence par microscopie électronique á transmission de l'abondance de bactáries symbiotiques dans la branchie de mollusques bivalves de sources hydrothermales profondes. CR Acad Sci Paris 298: 487-492

Fisher CR (1990) Chemoautotrophic and methanotrophic symbioses in marine invertebrates. Rev Aquat Sci 2: 399-436

Foster MS, Nigg EW, Kiguchi LM, Hardin DD, Pearse JS (2003) Temporal variation and succession in an algaldominated high intertidal assemblage. J Exp Mar Biol Ecol 289:15-39

Fox M, Juniper SK, Vali H (2002) Chemoautotrophy as a possible nutritional source in the hydrothermal vent limpet Lepetodrilus fucensis. Cah Biol Mar 43:371-376

Fustec A, Desbruyères D, Juniper SK (1987) Deep sea hydrothermal vent communities at $13^{\circ} \mathrm{N}$ on the East Pacific Rise: microdistribution and temporal variations. Biol Oceanogr $4: 121-164$

Grassle JF (1986) The ecology of deep-sea hydrothermal vent communities. Adv Mar Biol 23: 301-362

Hayek LA, Buzas MA (1997) Surveying natural populations. Columbia University Press, New York

Haymon RM, Macdonald KC (1985) The geology of deep-sea hot springs. Am Sci 73:441-449

Haymon RM, Fornari D, Edwards E, Carbotte S, Wright D, Macdonald KC (1991) Hydrothermal vent distribution along the 
East Pacific Rise crest $\left(9^{\circ} 09-54^{\prime} \mathrm{N}\right)$ and its relationship to magmatic and tectonic processes on fast-spreading midocean ridges. Earth Planet Sci Lett 104:513-53

Haymon RM, Fornari DJ, Von Damm KL, Lilley MD and 11 others (1993) Volcanic eruption of the mid-ocean ridge along the East Pacific Rise crest at $9^{\circ} 45-52^{\prime} \mathrm{N}$ : Direct submersible observations of seafloor phenomena associated with an eruption event in April, 1991. Earth Planet Sci Lett 119:85-101

Hessler RR, Smithey WM, Boudrias MA, Keller CH, Lutz RA, Childress JJ (1988) Temporal change in megafauna at the Rose Garden hydrothermal vent (Galapagos Rift; eastern tropical Pacific). Deep-Sea Res 35:1681-1709

Horn HS (1976) Succession principles and applications. In: May RM (ed) Theoretical ecology. WB Saunders, Philadelphia, PA, p 187-204

Hubbell, SP (2001) The unified theory of biodiversity and biogeography. Princeton University Press, Princeton, NJ

Humphris SE, Herzig PM, Miller DJ, Alt JC, and 21 others (1995). The internal structure of an active sea-floor massive sulphide deposit. Nature 377:713-716

Johnson KS, Childress JJ, Beehler CL, Sakamoto CM (1994) Biogeochemistry of hydrothermal vent mussel communities: the deep-sea analog to the intertidal zone. Deep-Sea Res 41:993-1011

Jorgensen CB (1990) Bivalve filter feeding, hydrodynamics, bioenergetics, physiology and ecology. Olsen \& Olsen, Fredensborg

Klitgord KD, Mudie JD (1974) The Galapagos spreading center: a near-bottom geophysical survey. Geophys J R Astr Soc 38:563-586

Lehane C, Davenport J (2002) Ingestion of mesozooplankton by 3 species of bivalve; Mytilus edulis, Cerastoderma edule and Aequipecten opercularis. J Mar Biol Assoc UK 82:615-619

Lehane C, Davenport J (2004) Ingestion of bivalve larvae by Mytilus edulis: experimental and field demonstrations of larviphagy in farmed blue mussels. Mar Biol 145:101-108

Le Pennec M, Hily A (1984) Anatomy, structure and ultrastructure of the gill of a deep sea hydrothermal vent mytilid. Oceanol Acta 7:517-523

Marsh AG, Mullineaux LS, Young CM, Manahan DT (2001) Larval dispersal potential of the tubeworm Riftia pachyptila at deep-sea hydrothermal vents. Nature 411:77-80

Menge BA, Branch GM (2001) Rocky intertidal communities. In: Bertness MD, Gaines SD, Hay ME (eds) Marine community ecology. Sinauer Associates, Sunderland, MA, p 221-251

Micheli F, Peterson CH, Mullineaux LS, Fisher CR, Mills SW, Sancho G, Johnson GA, Lenihan HS (2002) Predation structures communities at deep-sea hydrothermal vents. Ecol Monogr 72:365-382

Mullineaux LS, Fisher CR, Peterson CH, Schaeffer SW (2000) Tubeworm succession at hydrothermal vents: use of biogenic cues to reduce habitat selection error? Oecologia 123:275-284

Mullineaux LS, Peterson CH, Micheli F, Mills SW (2003) Successional mechanism varies along a gradient in hydrothermal fluid flux at deep-sea vents. Ecol Monogr 73:523-542

Page HM, Fiala-Medioni A, Fisher CR, Childress JJ (1991) Experimental evidence for filter-feeding by the hydrothermal vent mussel, Bathymodiolus thermophilus. DeepSea Res 38:1455-1461

Pradillon F, Shillito B, Young CM, Gaill F (2001) Developmental arrest in vent worm embryos. Nature 413:698-699

Raulfs EC, Macko SA, Van Dover CL (2004) Tissue and symbiont condition of mussels (Bathymodiolus thermophilus) exposed to varying levels of hydrothermal activity. J Mar Biol Assoc UK 84:229-234
Sarrazin, J, Juniper SK (1999) Biological characteristics of a hydrothermal edifice mosaic community. Mar Ecol Prog Ser 185:1-19

Sarrazin J, Robigou V, Juniper SK, Delaney JR (1997) Biological and geological dynamics over four years on a hightemperature sulfide structure at the Juan de Fuca Ridge hydrothermal observatory. Mar Ecol Prog Ser 153:5-24

Seed R (1996) Patterns of biodiversity in the macro-invertebrate fauna associated with mussel patches on rocky shores. J Mar Biol Assoc UK 76:203-210

Shank TM, Fornari DJ, Von Damm KL, Lilley MD, Haymon RM, Lutz RA (1998) Temporal and spatial patterns of biological community development at nascent deep-sea hydrothermal vents ( $9^{\circ} \mathrm{N}$, East Pacific Rise). Deep-Sea Res II 45:465-516

Sousa WP (2001) Natural disturbance and the dynamics of marine benthic communities. In: Bertness MD, Gaines SD, Hay ME (eds) Marine community ecology. Sinauer Associates, Sunderland, MA, p 85-130

Tamburri MN, Zimmer-Faust RK (1996) Suspension-feeding: basic mechanisms controlling recognition and ingestion of larvae. Limnol Oceanogr 41:1188-1197

Tanner JE, Hughes TP, Connell JH (1994) Species coexistence, keystone species, and succession a sensitivity analysis. Ecology 75:2204-2219

Terborgh, J, Foster, RB, Nunez VP (1996) Tropical tree communities: A test of the nonequilibrium hypothesis. Ecology 77:561-567

Thompson G, Bryan WB, Humphris SE (1989) Axial volcanism on the East Pacific Rise, 10-12 degrees N. In: Saunders AD, Norry MJ (eds) Magmatism in the ocean basins. Geol Soc Spec Publ 42:181-200

Timko P (1979) Larviphagy and oophagy in benthic invertebrates: a demonstration for Dendraster excenticus (Echinoidea). In: Stancyk SE (ed) Reproductive ecology of marine invertebrates. University of South Carolina Press, Columbia, SC, p 91-98

Tsurumi M, Tunnicliffe V (2001) Characteristics of a hydrothermal vent assemblage on a volcanically active segment of Juan de Fuca Ridge, northeast Pacific. Can J Fish Aquat Sci 58:530-542

Tsurumi M, Tunnicliffe V (2003) Tubeworm-associated communities at hydrothermal vents on the Juan de Fuca Ridge, northeast Pacific. Deep-Sea Res I 50:611-629

Tunnicliffe V, Embley RW, Holden JF, Butterfield DA, Massoth GJ, Juniper SK (1997) Biological colonization of new hydrothermal vents following an eruption on Juan de Fuca Ridge. Deep-Sea Res I 44:1627-1644

Underwood AJ, Chapman MG, Connell SD (2000) Observations in ecology: you can't make progress on processes without understanding the patterns. J Exp Mar Biol Ecol 250:97-115

Van Dover CL (2002a) Community structure in deep-sea hydrothermal vent mussel beds. Mar Ecol Prog Ser 230: 137-158

Van Dover CL (2002b) Trophic relationships among invertebrates at the Kairei hydrothermal vent field (Central Indian Ridge). Mar Biol 141:761-772

Van Dover CL (2003) Variation in community structure within hydrothermal vent mussel beds on the East Pacific Rise. Mar Ecol Prog Ser 235:55-66

Van Dover CL, Fry B (1994) Microorganisms as food resources at deep-sea hydrothermal vents. Limnol Oceanogr 39:51-57

Ward ME, Jenkins CD, Van Dover CL (2003) Functional morphology and feeding strategy of the hydrothermal-vent polychaete Archinome rosacea (Amphinomidae). Can J Zool 81:582-590

Woodin SA (1976) Adult-larval interactions in dense infaunal assemblages: Patterns of abundance. J Mar Res 34:25- 41 